\title{
Optimizing Small Enterprises Through OD, Values, and Innovation
}

\author{
Wustari L. Mangundjaya \\ Faculty of Psychology \\ Universitas Indonesia \\ Depok, Indonesia \\ wustari@gmail.com, wustari@ui.ac.id
}

\begin{abstract}
Every organization, including Small Medium Enterprises (SME) organization, has to grow and develop. Consequently, there are many kinds of approaches to innovation program and organizational development. On the other hand, it is undeniable the impact of culture on individual and group. The previous study showed that people and organization had their values, norm, and learning and that has also been affected by the national culture. The objective of this paper is to discuss the role of organizational development and innovation in Small Medium Enterprise, in a society, and culture. This discussion is based on the literature review as well as reviewing research findings. The objective of this paper is to develop the awareness of the role of culture in innovation and organizational development in Small Medium Enterprises.
\end{abstract}

Keywords - Innovation, Organizational Development, Small Medium Enterprises and Values.

\section{INTRODUCTION}

The concept of Organizational Development (OD) has been widely used and discussed since one decade ago. However, as pointed out by many authors and researchers [1]-[2], little thought and discussion have gone into specifying more precisely what is OD efforts regarding developing innovation in the organization especially in Small Medium Enterprises. Organizations operate in very challenging environments, which makes developing innovation capability is vital. The study of Dobni [3] showed that firms who possess high innovation orientations engage in value creation strategies. Innovation plays a critical role in the survival and growth of organizations [4]. Meanwhile, people and organizations stay in the society who have their own culture, values, and norms; This paper discuss the implementation of OD intervention to develop innovation in SME organization as well as the role of values in this issue, using literature view and analysis of research findings by [5]-[8].

\section{REVIEW OF LITERATURES}

\section{A. $O D$ and its process}

There are many definitions of OD, one of the definitions in relation with value creation is mentioned as follows: Organizational Development (OD) is mostly theory-based, process focused and value driven, with the objective to improve organization's problem solving and renewal process [9]. About OD process, some theories consider social interaction as an element of change [10]. Organizations consist of a plurality of perspectives which revealed through conversation. Worley and Feyerherm [11], also stated that understanding OD has two insights, both social constructionism and shared perception which can be established by dialogue. Consequently, social interaction is the primary vehicle for organizational change processes. Many of the OD interventions, approach, techniques, and methods incorporate some form of discussions and communication, therefore, can be interpreted as fitting the social constructionist approach to organizational change field [2].

\section{B. Innovation}

Innovation capability has been suggested to be a multifaceted construct. According to Neely et al. [12], an organization's innovation capability can be described as its potential to generate innovative outputs. Hotho and Champion [13], argues that the source of innovation is from the creativity and innovator capability of people. As a result, innovation and creativity are impossible without the participation of people and supports from the organization.

The previous study conducted by Saunila and Ukko [14], argues that innovation capability divides into seven aspects. There are: a) participatory leadership culture, b) ideation and organizing structures, c) work climate and wellbeing, d) knowhow development, e) regeneration, f) external knowledge, and g) individual activity. The explanations of each dimension are as follows: 1) Participatory leadership culture, refers to the overall atmosphere of the organization that supports, motivates and leadership that facilitates innovation. 2) Ideation and organizing structures are related to the structures and systems that generate, develop and implement changes. 3) Work climate and wellbeing, represent the welfare of the employees and further the work climate for innovation development, including collaboration and values. 4) Know-how development includes skills, knowledge, and experience of the employees that play a role in innovation capability. 5) An external knowledge, aspect highlights the importance of the proper behavior of exploiting external networks and expertise to the overall organizational innovation capability. 6) Regeneration reflects an organization's ability to learn from earlier experience and to use that knowledge to create and 
develop innovations. In this regard, agencies should also need to be tolerant of the mistakes that will occur and allow for recovery and learning from failures) to achieve higher innovation capability [15]-[16]. 7) Employees' innovation, refer to capability and activity needed to form the organization's overall innovation capability.

\section{Values, Culture and Organizational Culture}

Based on the theory and concept by Hofstede and Hofstede [17] and [18], it can be concluded that there are some values and culture in the society that related with norms, value and culture of the organization, and the people who work in that team. Meanwhile, organizational culture is a standard set of beliefs, values, norms, and customs that control the behavior of members of the organization. It is specific to each group and shaped to a large extent by the management. Sikorski [19] also mentioned that the deliberate modification of values and norms form the organizational culture lead to new, cohesive and more efficient organization. When organizational change applies, consequently it also has an impact on the relationships between the shaped values, the strategy, the structure and the process of the organization, which also requires the elements of culture and society in which the institutions operates.

As this paper discussion are merely on the topics of innovation, change, and development, consequently, a study of values, norms and culture are also limited to the innovation, change, and growth. Some of the work-related values are as follows: 1) Uncertainty Avoidance [17]-[18], These workrelated values show that people will feel okay with the condition of ambiguous and uncertain if he or she has low uncertainty avoidance. According to previous studies [17],[6], Indonesian employees have low uncertainty avoidance's score. With the feeling of relax and no stress, people is assumed to be more creative and innovative. Mangundjaya's results [5] also showed that Indonesian people as creative people. 2) Future orientation refers to values and direction of the people, which is more on future and not based on traditional and tradition. Finding also showed that Indonesian people are more future orientation than current orientation. With this kind of value, people are more adaptive to new ideas and innovation. 3) Individualism vs. collectivism, the previous study showed by Hofstede \& Hofstede [17] showed that Indonesian people are more collective than individualist, in contrast, Mangundjaya's findings [6] showed that Indonesian people are more individualism than collectivism. 4) Power distance is the relationship of people with the seniority, rank, and status. In this regard, studies showed by Hofstede \& Hofstede [17] as well as Mangundjaya's [6] showed similar findings that Indonesian people are still in moderate to high power distance. With this kind of value, Indonesian people always pay respect to elderly, seniority and hierarchy. Although, if it compares with Hofstede's findings [17] the score is smaller or in moderate level [6].

\section{Small Medium Enterprises}

At present, in this competitive world, the ability to introduce various concepts and business models is a prerequisite for the successful growth of enterprise's competitiveness. This ability is to no small extent closely linked to the strength of the companies to create, implement and disseminate a variety of innovative solutions. In general, the characteristics of Small Medium Enterprises in Indonesia are as follows: flat organizational hierarchy, focus on innovation and creativity, and flexible climate and communication, with decision making mostly in the hands of $\mathrm{CEO}$ or the leader. Moreover, in Small Medium Enterprises organization just like in any other companies, leader, and its leadership style is one of the vital driving forces for improving firm performance and productivity [20]. As a result, if the managers of SMEs, which usually have low organizational hierarchy only pay attention to day to day operation, then the innovation culture will not be developed [20].

\section{E. OD, Culture and Innovation development in Small Medium Enterprises}

House et al., [18], mentioned that societal, cultural values and practices affect organizational culture and procedure. Societal and corporate culture and practices influence the process of the organization. An organization seeks to continuously improve itself as a whole, by proactively adopting organizational learning activities to manage both internal and external change situations ahead of time [21]. Consequently, as a change leader. First, he/she should enable to identify the culture of the organization, what kind of organizational culture that represented by the people and management. In this regard, change leader should have the ability to assess the work values of the people, such as its value on uncertainty avoidance, future orientation, individualism or collectivism, and power distance of the organization's values. By understanding their work values, change leader can plan the OD steps to develop organizational innovation capability. Second, a leader should become a role model and give supports to innovation activities, like the ability to lead, direct, and support is essential in creation innovation capability. The participative leadership style seems more suitable to create organizational innovation capability. Third, this ability of the leader should be supported with the infrastructure of the organization, both physically and psychologically or well-being of the people. The climate of trust also has to be developed, as organizational faith is essential on developing a commitment to change [7]. Fourth, a leader should also empower people with skills and knowledge, knowledge not only about internal learning about the organization, but also experience about the external institutions, both is essential. This concept supported the previous findings of Mangundjaya[7]-[8], which people's psychological empowerment is necessary on a commitment to change. Last, leader should enable to develop the conducive climate of innovation, as with this positive climate people will feel confident to try new ideas and not afraid of making mistakes.

\section{Discussion, CONCLUSION \& RECOMMENDATION}

Every organization and enterprises must continuously create new knowledge and skills to be able to transform the institutions and its products and services. The study of Dobni [3] concluded that firms which possess high innovation orientations engage in value creation strategies. Innovation itself can be regarded as an organizational capability because it 
is an act that deploys resources with a new ability to create value [22]. In this regard, leadership is one of the fundamental driving forces for improving firm performance [20]. Based on the findings of [17],[6], it showed that Indonesian people are more having high power distance, or have respect for the seniority. With this kind of value, leader plays a very critical role in the organization. Moreover, Zhu et al. findings [20] also showed that if the managers of SMEs (which usually have low organizational hierarchy levels) concentrate too much on the sufficient level actions, they may ignore their primary task management of the firm. Meanwhile, an active participation of the managers in operational activities may decrease employee idea generation and creativity. Moreover, there is also needs to foster an innovative culture in which individuals are always encouraged to generate new ideas, knowledge, and solutions. In this regard, Goh [23] suggested a culture which emphasizes problem solving, creativity and innovation. Individuals should also be empowered, by empowering people, they will have more opportunities to explore new approaches. The element of openness is also significant, whereby people shared mistakes without the fear of punishment [24]. In this respect, errors and failures are not only tolerated but allowed and forgiven. Making mistakes should be viewed as an investment process in individuals because it can be a crucial source of learning.

Previous study showed that leader is essential in organizational change and development. Consequently, change leader to conduct organizational change and development should be able to understand the social system, as well as the culture of the society and organization. In this regard, Small Medium Enterprises to exist and competitive should be able to conduct organizational change and development. Understanding the process and concepts of OD (organizational development), as well as innovation and culture are some of the knowledge, skills, and abilities that must be mastered by the leader. However, this paper only based on a theoretical review, and previous research findings [5]-[8]. As a result, in order to have a clear picture of organizational change and development process as well as developing innovation capability in a Small Medium Enterprise organization, future research should be conducted.

To conclude, organizational change, development, and innovation cannot be developed if the change leader is not paying attention to the culture of the organization and the society. In this regard, leader and manager in SMEs should be able to create high participation in order to increase creativity and innovation. Moreover, to develop SME's organization, a leader should be aware of the importance of change. In this regard, if the CEO has not enough time and ability to direct, lead and manage the organization to master the innovation capability, he/she should assign and delegate this task to internal or external organizational change and development consultant.

\section{REFERENCES}

[1] R.J. Marshak, R.J. Organization development as a professional organization a field, in B.B. Jones and M. Brazzel (eds) The NTL Handbook of Organization Development Organization Change; Principles, Practices, and Perspectives, pp. 13-27. San Francisco, CA: Pfeiffer, 2006.

[2] H.Sminia and A. Van Nistelrooij, A (2010), Theoretical foundations for organizational development, Journal of Change Management, Vol 10, no. 4, pp. 387-391, 2010.

[3] C.B. Dobni, The relationship between an innovation orientation and competitive strategy, International Journal of Innovation Management, Vol. 14 No. 2, pp. 331-357, 2010.

[4] D. Francis, and J. Bessant, Targeting innovation and implications for capability development, Technovation, Vol. 25 No. 3, pp. $171-183$, 2005.

[5] W. L. Mangundjaya, Team Preferences: Cross-Cultural Study between Indonesia and Australia, Thesis, Limited Publication, University of Queensland, Brisbane, Australia, 1992.

[6] W.L. Mangundjaya, Is There Cultural Change in The National Cultures of Indonesia? in Kasima, Y; Kashima, E; Beatson, R; Steering the Cultural Dynamics, Selected Papers from the 2010 Congress of the International Association for Cross-Cultural Psychology, 2013.

[7] W.L.H. Mangundjaya, People or trust in building commitment to change? The Journal of Developing Areas, Special Issue on Kuala Lumpur Conference, August 2014, Volume 49, No. 5, pp 67-78, 2015.

[8] W. L. Mangundjaya, Psikologi dalam Perubahan Organisasi, Swascita Publishing, Jakarta, Indonesia, 2016

[9] M. Y, Cheung-Judge, and L. Holbeche, Organization Development, A practitioner's guide for OD and HR, Kogan Page, London UK, 2012

[10] J.R. Austin, and J.M. Bartunek, A Framework to map a practice as organization development, in Theories and practices of organization development, J.V. Gallos (Ed.), Jossey-Bass, USA, 2006

[11] C.G. Worley and A.E. Feyerherm, Reflections on the Future of Organization Development, The Journal of Applied Behavioral Science, Vol.39:1, p 97-115, 2003.

[12] A. Neely, R. Filippini, C. Forza, A. Vinelli, and J. Hii, A framework for analyzing business performance, firm innovation and related contextual factors: perceptions of managers and policy makers in two European regions. Integrated Manufacturing Systems, Vol. 12 No. 2, pp. $114-$ 124,2001

[13] S. Hotho, and K. Champion, Small businesses in the new creative industries: innovation as a people management challenge, Management Decision, Vol. 49 No. 1, pp. 29 - 54, 2011.

[14] M. Saunila and J. Ukko, Intangible aspects of organizational innovation capability in Finnish SMEs, Proceedings of 6th International Forum on Knowledge Asset Dynamics, Tampere, June, 2011.

[15] D. Wan, C.H. Ong, and F. Lee, Determinants of firm innovation in Singapore Technovation, Vol. 25 No. 3, pp. 261 - 268, 2005

[16] B. Lawson, and D. Samson, Developing innovation capability in organizations: a dynamic capabilities approach, International Journal of Innovation Management, Vol. 5 No. 3, pp. 377 - 400, 2001.

[17] G. Hofstede, G. and G.J. Hofstede, Cultures and Organizations: Software of the Mind (2nd Ed.). New York: McGraw-Hill, 2005.

[18] R.J, House, R.J et al. (2004), Culture, Leadership and Organizations, The Global study of 62 societies, Sage Publications, Thousand Oakes, London, 2004.

[19] Cz. Sikorski, Kultura organizacyjna, C.H. Beck, Warszawa, 2002.

[20] W. Zhu, L.K.H, Chew, and W.D. Spangler, CEO transformational leadership \& organizational outcomes: the mediating role of human: capital: enhancing human resource management, The Leadership Quarterly, Vol. 16 No. 1, pp. 39 - 52, 2005.

[21] T.G. Cummings and G. Worley, Practicing Organization Development, A guide for leading change, 2009 
[22] C.C. Yang, P.B. Marlow, and C.S. Lu, Assessing resources, logistics service capabilities, innovation capabilities and the performance of container shipping services in Taiwan, International Journal of Production Economics, Vol. 122 No. 1, pp. 4 - 20, 2009
[23] S.C. Goh, Managing effective knowledge transfer: an integrative framework and some practical implications, Journal of Knowledge Management, Vol. 6 No. 1, pp. 23-30, 2002.

[24] K.Y. Wong, Critical success factors for implementing knowledge management in small and medium enterprise, Industrial Management \& Data Systems, Vol. 105 No. 3, 2005 pp. 261-279, 2005. 